\title{
Trabalhonecessário
}

Issn: $1808-799 X$

ano 13, número $21-2015$

\section{A FORMAÇÃO DOS FORMADORES DA CLASSE TRABALHADORA NO BRASIL: LUTA DE CLASSES E DISPUTA DE PROJETOS.}

\author{
Márcia Morschbacher ${ }^{1}$ \\ Celi Zulke Taffarel ${ }^{2}$
}

\section{Resumo}

Este artigo tem como objetivo analisar a atual situação da formação dos professores no Brasil, tendo em conta os distintos projetos de formação em disputa, consoante as classes em luta no modo de produção capitalista. Analisa informações dos bancos de dados do Instituto Nacional de Estudos e Pesquisas Educacionais Anísio Teixeira (INEP/MEC) sobre a Educação Básica e o Ensino Superior, relativamente à demanda concreta de professores para a rede pública de ensino básico na cidade e no campo e à situação da formação destes professores, tendo em conta dados sobre os professores que atuam na Educação Básica e os cursos responsáveis por esta formação (número, modalidades, vagas, matrículas e instituições). Realiza também revisão bibliográfica acerca do tema "formação de professores", evidenciando os projetos que disputam a direção desta formação no plano da política educacional e da teoria pedagógica, considerando os antagônicos interesses das classes que disputam o controle dos meios de produção e dos instrumentos políticos no atual grau de desenvolvimento deste modo de produção. Evidencia a expansão dos cursos superiores para a formação dos professores no país, sobretudo no Ensino Superior privado e na modalidade a distância e, por outro lado, a demanda por professores com

\footnotetext{
1 Universidade Federal da Bahia (UFBA), Brasil - mm.edufisica@yahoo.com.br

2 Universidade Federal da Bahia (UFBA), Brasil - taffarel@ufba.br 


\section{Trabalhonecessário}

Issn: $1808-799 X$

ano 13, número $21-2015$

formação em nível superior (licenciatura) - cerca de $1 / 3$ dos professores que atuam na Educação Básica não possui formação neste nível. Analisa que as recentes reformas educacionais têm como meta compatibilizar a formação dos formadores da classe trabalhadora ao projeto de mundialização da educação para a Educação Básica (implementado no país desde a década de 1990), tendo em conta a necessidade de rebaixamento do valor da força de trabalho e de contenção dos trabalhadores em uma conjuntura de crise do modo de produção e de acirramento dos conflitos entre capital e trabalho. O referencial privilegiado por este projeto hegemônico situa-se nas pedagogias do aprender a aprender, marcadas por uma teoria do conhecimento relativista e uma pedagogia alicerçada na supervalorização das experiências individuais e cotidianas em detrimento do trato com o conhecimento científico. Em contraposição a este projeto, tem-se o projeto reivindicado pela classe trabalhadora, cujas bases fundamentais são a reivindicação do acesso ao conhecimento na sua expressão mais desenvolvida (a ciência) e tratado de acordo com os pressupostos da concepção materialista e dialética da história, bem como o desenvolvimento de uma consistente formação política.

Palavras-chave: Educação Básica; formação de professores; formação da classe trabalhadora; projetos de formação.

\section{Abstract}

This article aims to analyze the present situation of the teacher formation in Brazil, taking into account the different formation projects in dispute, according the classes in fight on the capitalist mode of production. It analyses informations from Databases of Instituto Nacional de Estudos e Pesquisas Educacionais Anísio Teixeira (INEP/MEC) about Basic Education and Higher Education, relatively to the concrete demand of teacher to the public basic education in the city and 


\section{Trabalhonecessário}

Issn: $1808-799 X$

ano 13, número $21-2015$

countryside and situation of formation these teachers, taking into account the data about the teachers that work in Basic Education and the courses responsible by this formation (number, modalities, vacancies, registrations and institutions). It realizes too a bibliographic revision about the theme "teacher formation", indicating the projects that dispute the direction this formation on the plan of educational policy and the pedagogical theory, considering the antagonist interests of the classes that dispute the control of means of production and the political instruments in the present degree of development this mode of production. It demonstrates the expansion of higher education courses for teacher formation in the country, especially in private higher education and distance learning courses and, by other side, the demand by teachers with higher education level (degree course) - approximately $1 / 3$ of teachers that work in Basic Education does not have formation in this level. It analyses that the recent educational reforms has like target made compatible the formation of teachers with the globalisation project of education to the Basic Education (implemented in the country since the 1990s), taking into account the necessity of abasement of workforce value and workers' restraint in a conjuncture of crisis of the mode of production and aggravation of conflicts between capital and work. The privileged framework by this hegemonic project are the pedagogies learning to learn, marked by a relativist knowledge theory and a pedagogy based in overvaluation of individual and daily life experiences rather than treatment with the scientific knowledge. In opposition to this project, there is the project claimed by working class, whose fundamental basis are the claim of the access to knowledge in its most developed expression (the science) and treated according with the postulates of materialist and dialectical conception of history, as well as the development of a consistent political formation. 


\section{Trabalhonecessário}

Issn: $1808-799 X$

ano 13, número $21-2015$

Keywords: Basic Education; teacher formation; formation of class working; formation projects.

\section{Introdução}

Este artigo analisa a disputa de projetos de formação de professores para a Educação Básica, travada na luta entre capital e trabalho em andamento na formação social brasileira. Apresentamos uma síntese acerca dos antagônicos projetos que disputam a direção da formação de professores no país, evidenciando a sua base teórica e os interesses de classes explícitos e/ou subjacentes. Trabalhamos com os dados disponibilizados pelo Inep/MEC relativos a) aos professores que atuam na Educação Básica; b) à demanda concreta de professores para a Educação Básica e o Ensino Superior para a rede pública; c) os cursos superiores responsáveis por esta formação; d) à situação da formação destes professores, relacionando estes dados com os interesses em disputa

\section{A demanda por professores para a Educação Básica no Brasil e a formação destes professores}

Trabalhamos com os dados das Sinopses da Educação Básica e da Educação Superior do Inep/MEC para obter uma breve caracterização dos professores que atuavam na Educação Básica no Brasil, no período de 2010 a 2013. Inicialmente, apresentamos dados sobre o número de matrículas, de escolas públicas e privadas e de professores que atuavam na Educação Básica no período considerado. Na segunda etapa, são apresentados dados referentes ao nível de formação destes professores e a oferta de cursos de licenciatura no 


\section{Trabalhonecessário}

Issn: $1808-799 X$

ano 13, número $21-2015$

país (cursos e matrículas nas modalidades presenciais e a distância em Instituições de Ensino Superior (IES) públicas e privadas).

Tabela 1: Número de Matrículas na Educação Básica - Brasil e Regiões Geográficas (2010-2013)

\begin{tabular}{|l|c|c|c|c|}
\hline & $\mathbf{2 0 1 0}$ & $\mathbf{2 0 1 1}$ & $\mathbf{2 0 1 2}$ & $\mathbf{2 0 1 3}$ \\
\hline Brasil & 51.549 .889 & 50.972 .619 & 50.545 .050 & 50.042 .448 \\
\hline Norte & 5.134 .960 & 5.121 .317 & 5.159 .675 & 5.144 .488 \\
\hline Nordeste & 15.709 .861 & 15.470 .148 & 15.227 .827 & 14.968 .836 \\
\hline Sudeste & 20.334 .290 & 20.120 .683 & 19.958 .462 & 19.806 .604 \\
\hline Sul & 6.700 .104 & 6.596 .666 & 6.551 .598 & 6.484 .103 \\
\hline Centro-Oeste & 3.670 .674 & 3.663 .805 & 3.647 .488 & 3.638 .417 \\
\hline
\end{tabular}

Fonte: Inep - Sinopse da Educação Básica (anos-base: 2010, 2011, 2012 e 2013).

\section{Gráfico 1: Evolução no número de matrículas na Educação Básica Brasil e Regiões Geográficas (2010-2013)}

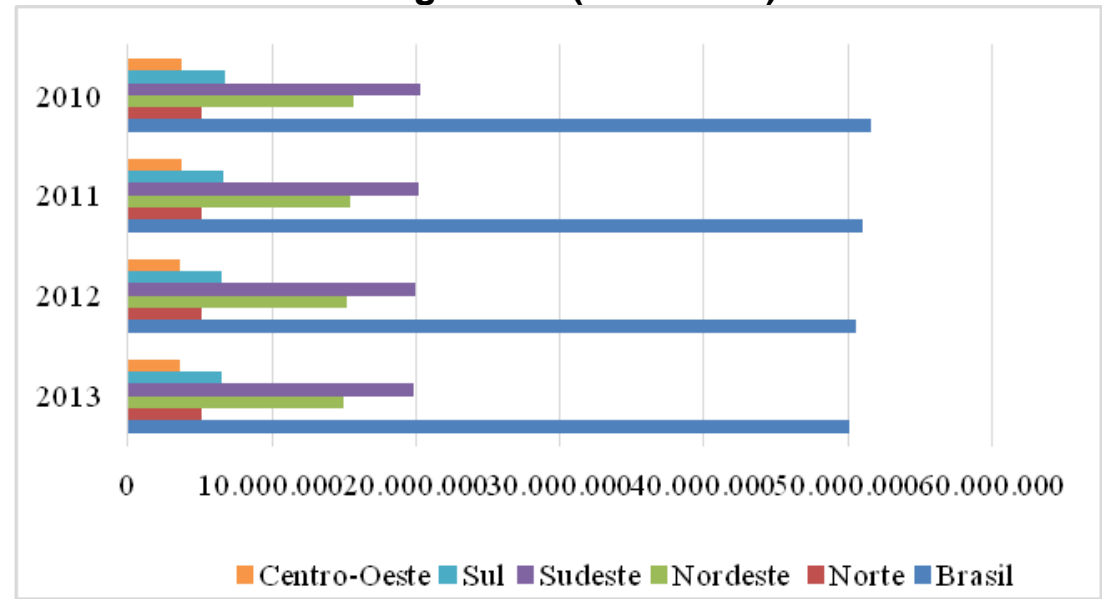

Fonte: Inep - Sinopse da Educação Básica (anos-base: 2010, 2011, 2012 e 2013).

A Tabela 1 e o Gráfico 1 apresentam as matrícula na Educação Básica no país e regiões entre 2010 e 2013. Evidencia-se que o país possuía uma média de 50,7 milhões de matrículas, sendo que as regiões Nordeste e Sudeste apresentavam o maior número. Destaca-se um decréscimo de 1.507.441 matrículas, observado também em todas as regiões. A exceção é a região Norte que, em 2012, teve um aumento de 9.488 matrículas. O Nordeste teve um 


\section{Trabalhonecessário}

Issn: $1808-799 X$

ano 13, número $21-2015$

decréscimo de 741.025 matrículas, o Sudeste, 527.686, o Sul, 216.001 e o Centro-Oeste, 32.257.

Tabela 2: Número de matrículas na Educação Básica - Rede Pública e Rede Privada (2010-2013)

\begin{tabular}{|l||c|c||c|c||c|c||c|c|}
\hline \multicolumn{1}{|c||}{} & \multicolumn{2}{c||}{ 2010 } & \multicolumn{2}{c||}{ 2011 } & \multicolumn{2}{c||}{ 2012 } & \multicolumn{2}{c|}{ 2013 } \\
\cline { 2 - 9 } & Pública & Privada & Pública & Privada & Pública & Privada & Pública & Privada \\
\hline Brasil & 43.989 .507 & 7.560 .382 & 43.053 .942 & 7.918 .677 & 42.222 .831 & 8.322 .219 & 41.432 .416 & 8.610 .032 \\
\hline Norte & 4.764 .016 & 370.944 & 4.731 .294 & 390.023 & 4.733 .615 & 426.060 & 4.698 .082 & 446.406 \\
\hline Nordeste & 13.660 .499 & 2.049 .362 & 13.331 .521 & 2.138 .627 & 12.930 .492 & 2.297 .335 & 12.618 .367 & 2.350 .469 \\
\hline Sudeste & 16.693 .810 & 3.640 .480 & 16.283 .311 & 3.837 .372 & 15.973 .468 & 3.984 .994 & 15.678 .264 & 4.128 .340 \\
\hline Sul & 5.793 .909 & 906.195 & 5.655 .180 & 941.486 & 5.571 .612 & 979.986 & 5.460 .546 & 1.023 .557 \\
\hline $\begin{array}{l}\text { Centro- } \\
\text { Oeste }\end{array}$ & 3.077 .273 & 593.401 & 3.052 .636 & 611.169 & 3.013 .644 & 633.844 & 2.977 .157 & 661.260 \\
\hline
\end{tabular}

Fonte: Inep - Sinopse da Educação Básica (anos-base: 2010, 2011, 2012 e 2013).

Os dados da Tabela 2 indicam que a rede privada de Educação Básica obteve um aumento de 1.049 .650 matrículas entre 2010 e 2013. As regiões Nordeste (301.107) e Sudeste (487.860) apresentaram o aumento mais expressivo. Estes dados indicam que, embora a Educação Básica seja ofertada de forma predominante na rede pública, a rede privada está em expansão no país.

Tabela 3: Percentual de matrículas na Educação Básica na rede pública e rede privada (2010-2013)

\begin{tabular}{|l||c|c||c|c||c|c||c|c|}
\hline \multicolumn{1}{|c|}{} & \multicolumn{2}{c|}{2010} & \multicolumn{2}{c|}{2011} & \multicolumn{2}{c|}{2012} & \multicolumn{2}{c|}{2013} \\
\cline { 2 - 9 } & Pública & Privada & Pública & Privada & Pública & Privada & Pública & Privada \\
\hline Brasil & $85,33 \%$ & $14,67 \%$ & $84,46 \%$ & $15,54 \%$ & $83,54 \%$ & $16,46 \%$ & $82,79 \%$ & $17,21 \%$ \\
\hline Norte & $92,78 \%$ & $7,22 \%$ & $92,38 \%$ & $7,62 \%$ & $91,74 \%$ & $8,26 \%$ & $91,32 \%$ & $8,68 \%$ \\
\hline Nordeste & $86,95 \%$ & $13,05 \%$ & $86,17 \%$ & $13,82 \%$ & $84,91 \%$ & $15,09 \%$ & $84,30 \%$ & $15,70 \%$ \\
\hline Sudeste & $82,10 \%$ & $17,90 \%$ & $80,93 \%$ & $19,07 \%$ & $80,03 \%$ & $19,97 \%$ & $79,16 \%$ & $20,84 \%$ \\
\hline Sul & $86,47 \%$ & $13,53 \%$ & $85,73 \%$ & $14,27 \%$ & $85,04 \%$ & $14,96 \%$ & $84,21 \%$ & $15,79 \%$ \\
\hline $\begin{array}{l}\text { Centro- } \\
\text { Oeste }\end{array}$ & $83,83 \%$ & $16,17 \%$ & $83,32 \%$ & $16,68 \%$ & $82,62 \%$ & $17,38 \%$ & $81,83 \%$ & $18,17 \%$ \\
\hline
\end{tabular}

Fonte: Inep - Sinopse da Educação Básica (anos-base: 2010, 2011, 2012 e 2013). 


\section{Trabalhonecessário}

Issn: $1808-799 X$

ano 13 , número $21-2015$

Gráfico 2: Evolução das matrículas na rede pública de Educação Básica (2010-2013)

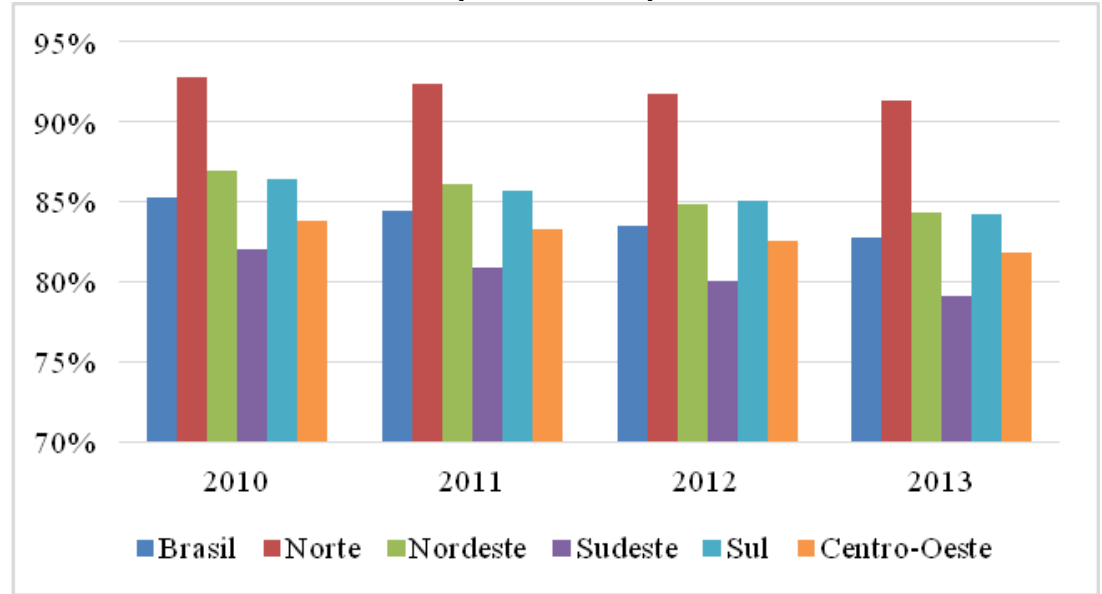

Fonte: Inep - Sinopse da Educação Básica (anos-base: 2010, 2011, 2012 e 2013).

Gráfico 3: Evolução das matrículas na rede privada de Educação Básica (2010-2013)

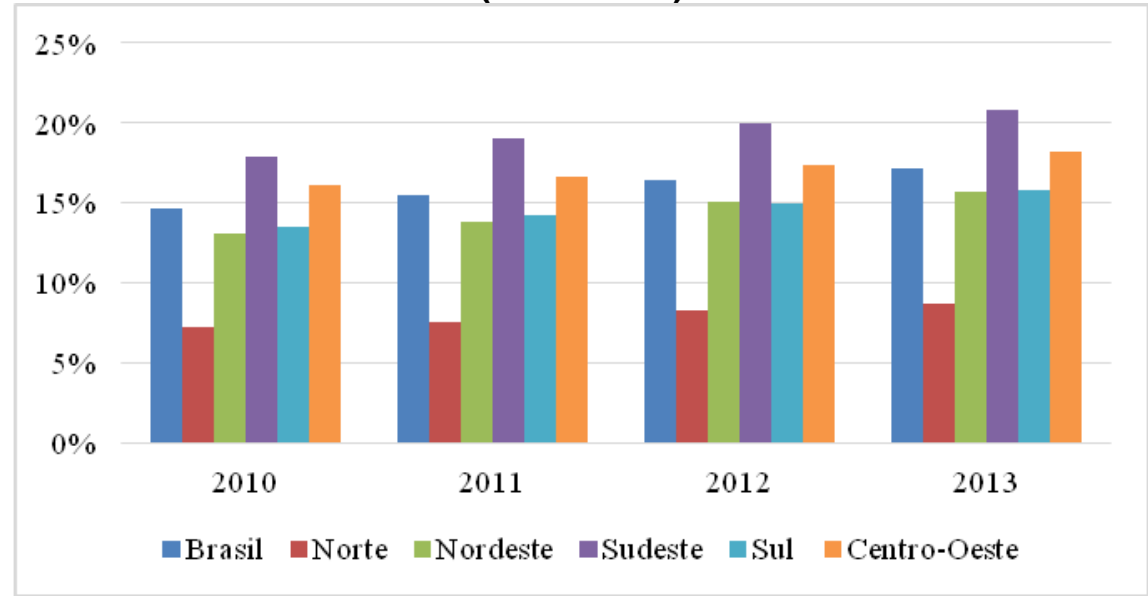

Fonte: Inep - Sinopse da Educação Básica (anos-base: 2010, 2011, 2012 e 2013).

Considerando-se que o aumento do número de matrículas na rede privada (Tabela 3 e Gráfico 3) e a diminuição do número total de matrículas na Educação Básica (Tabela 3 e Gráfico 2), evidencia-se que esta diminuição se refere exclusivamente à rede pública de Educação Básica. 


\section{Trabalhonecessário}

Issn: $1808-799 X$

ano 13, número $21-2015$

A Educação Básica ainda não foi universalizada no Brasil e este nível de ensino padece de graves problemas como o elevado percentual de abandono e de repetência escolar. A estes problemas, encontram-se associados: financiamento insuficiente consoante às necessidades, dificuldade de acesso à escola, irregularidade e baixa qualidade do transporte escolar, carência de professores, melhores salários e condições de trabalho para os professores e demais profissionais que trabalham nas escolas, infraestrutura insuficiente e/ou ausente, entre outros (TAFFAREL; RODRIGUES, MORSCHBACHER, 2013).

Tabela 4: Estabelecimentos escolares públicos e privados de Educação Básica

\begin{tabular}{|c|c|c|c|c|c|c|c|c|c|c|c|c|}
\hline & \multicolumn{3}{|c|}{2010} & \multicolumn{3}{|c|}{2011} & \multicolumn{3}{|c|}{2012} & \multicolumn{3}{|c|}{2013} \\
\hline & Total & Pública & Privada & Total & Pública & Privada & Total & Pública & Privada & Total & Pública & Privada \\
\hline Brasil & $\begin{array}{l}194 . \\
939\end{array}$ & $\begin{array}{l}158 . \\
650\end{array}$ & $\begin{array}{l}36 . \\
289\end{array}$ & $\begin{array}{l}193 . \\
047\end{array}$ & $\begin{array}{l}156 . \\
521\end{array}$ & $\begin{array}{c}36 . \\
883\end{array}$ & $\begin{array}{l}192 . \\
676\end{array}$ & $\begin{array}{l}154 . \\
616\end{array}$ & $\begin{array}{l}38 . \\
060\end{array}$ & $\begin{array}{l}190 . \\
706\end{array}$ & $\begin{array}{l}151 . \\
884\end{array}$ & $\begin{array}{l}38 . \\
822\end{array}$ \\
\hline Norte & $\begin{array}{l}24 . \\
280\end{array}$ & $\begin{array}{l}22 . \\
857\end{array}$ & 1.423 & $\begin{array}{l}23 . \\
998\end{array}$ & $\begin{array}{l}22 . \\
588\end{array}$ & 1.410 & $\begin{array}{l}23 . \\
851\end{array}$ & $\begin{array}{l}22 . \\
279\end{array}$ & 1.572 & $\begin{array}{l}23 . \\
551\end{array}$ & $\begin{array}{l}21 . \\
920\end{array}$ & 1.631 \\
\hline Nordeste & $\begin{array}{l}77 . \\
370\end{array}$ & $\begin{array}{l}67 . \\
707\end{array}$ & 9.663 & $\begin{array}{l}75 . \\
234\end{array}$ & $\begin{array}{l}65 . \\
609\end{array}$ & 9.625 & $\begin{array}{l}74 . \\
477\end{array}$ & $\begin{array}{l}64 . \\
240\end{array}$ & $\begin{array}{c}10 . \\
237\end{array}$ & $\begin{array}{l}72 . \\
242\end{array}$ & $\begin{array}{l}61 . \\
985\end{array}$ & $\begin{array}{c}10 . \\
257\end{array}$ \\
\hline Sudeste & $\begin{array}{l}58 . \\
210\end{array}$ & $\begin{array}{l}40 . \\
411\end{array}$ & $\begin{array}{l}17 . \\
799\end{array}$ & $\begin{array}{l}58 . \\
717\end{array}$ & $\begin{array}{l}40 . \\
389\end{array}$ & $\begin{array}{r}18 . \\
328\end{array}$ & $\begin{array}{l}59 . \\
021\end{array}$ & $\begin{array}{l}40 . \\
450\end{array}$ & $\begin{array}{l}18 . \\
571\end{array}$ & $\begin{array}{l}59 . \\
442\end{array}$ & $\begin{array}{l}40 . \\
381\end{array}$ & $\begin{array}{l}19 . \\
061\end{array}$ \\
\hline Sul & $\begin{array}{l}25 . \\
193\end{array}$ & $\begin{array}{l}20 . \\
084\end{array}$ & 5.109 & $\begin{array}{l}25 . \\
257\end{array}$ & $\begin{array}{l}20 . \\
006\end{array}$ & 5.251 & $\begin{array}{l}25 . \\
469\end{array}$ & $\begin{array}{l}20 . \\
052\end{array}$ & 5.417 & $\begin{array}{l}25 . \\
508\end{array}$ & $\begin{array}{l}19 . \\
976\end{array}$ & 5.532 \\
\hline $\begin{array}{l}\text { Centro- } \\
\text { Oeste }\end{array}$ & 9.886 & 7.591 & 2.295 & 9.841 & 7.572 & 2.269 & 9.858 & 7.595 & 2.263 & 9.963 & 7.622 & 2.341 \\
\hline
\end{tabular}

Fonte: Inep - Sinopse da Educação Básica (anos-base: 2010, 2011, 2012 e 2013). 


\section{Trabalhonecessário}

Issn: $1808-799 X$

ano 13, número $21-2015$

\section{Gráfico 4: Evolução do número de estabelecimentos públicos e privados} (2010-2013)

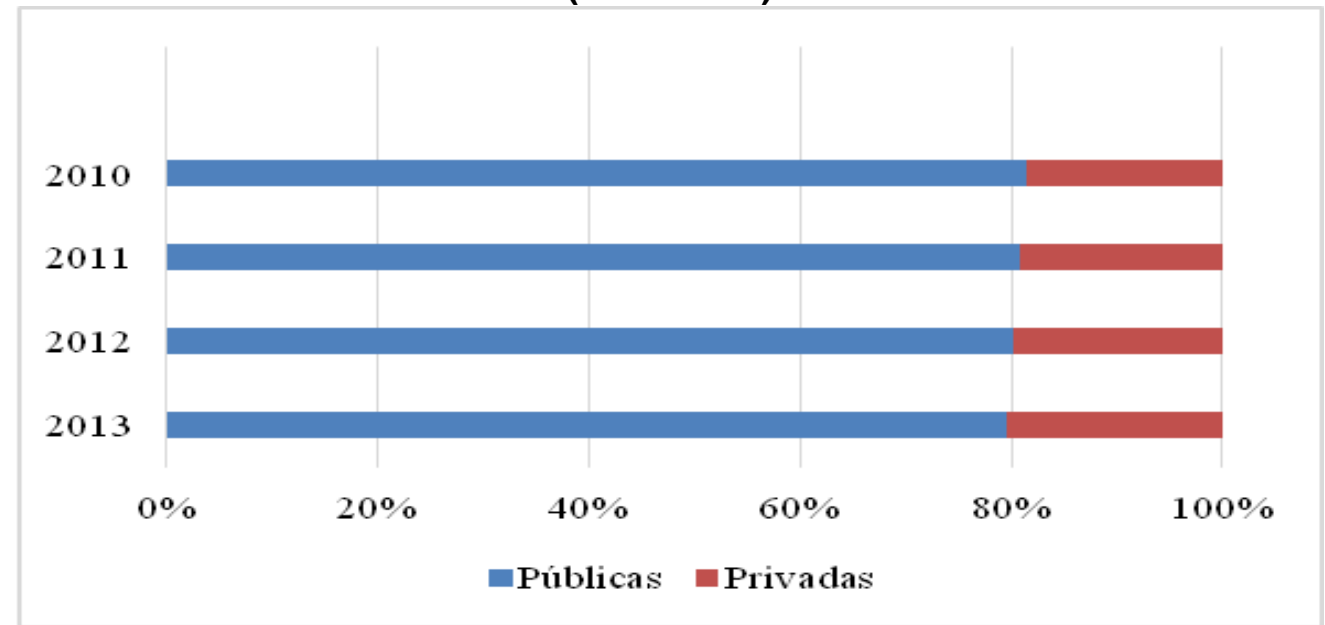

Fonte: Inep - Sinopse da Educação Básica (anos-base: 2010, 2011, 2012 e 2013).

Acompanhando a tendência da diminuição de matrículas, houve, em nível nacional, a diminuição do número de escolas públicas (Tabela 4 e Gráfico 4). Entre 2010 e 2013, o país teve 6.766 escolas públicas fechadas. Esta tendência é evidenciada em todas as regiões do país, todavia, há uma considerável disparidade: Norte: 937 escolas públicas fechadas; Nordeste: 5.722; Sudeste: 30; Sul: 108; Centro-Oeste: 329. A Região Nordeste apresentou o maior decréscimo no número de escolas ( $84 \%$ do total). Os estabelecimentos privados apresentaram um aumento de 2.533 escolas, sendo: Norte: 208; Nordeste: 594; Sudeste: 1.262; Sul: 423 e; Centro-Oeste: 46.

Tabela 5: Número de Funções Docentes na Educação Básica (2010-2013)

\begin{tabular}{|l|c|c|c|c|}
\hline & $\mathbf{2 0 1 0}$ & $\mathbf{2 0 1 1}$ & $\mathbf{2 0 1 2}$ & $\mathbf{2 0 1 3}$ \\
\hline Brasil & 2.005 .734 & 2.045 .350 & 2.101 .408 & 2.148 .023 \\
\hline Norte & 169.930 & 176.195 & 182.119 & 189.868 \\
\hline Nordeste & 600.796 & 603.359 & 613.367 & 619.358 \\
\hline Sudeste & 800.241 & 820.375 & 848.459 & 869.013 \\
\hline Sul & 290.927 & 298.736 & 310.507 & 319.379 \\
\hline $\begin{array}{l}\text { Centro- } \\
\text { Oeste }\end{array}$ & 143.840 & 146.685 & 146.956 & 150.405 \\
\hline
\end{tabular}

Fonte: Inep - Sinopse da Educação Básica (anos-base: 2010, 2011, 2012 e 2013).

TrabalhoNecessário - www.uff.br/trabalhonecessario; Ano 13, № 21/2015. 


\section{Trabalhonecessário}

Issn: $1808-799 X$

ano 13, número $21-2015$

No âmbito das funções docentes na Educação Básica (Tabela 5), observase uma tendência, nacional e regional, de aumento do número de professores no período de 2010 a 2013. Em nível nacional, houve um aumento de 142.289 professores, dos quais: Norte: 19.938; Nordeste, 18.562; Sudeste, 68.772; Sul, 28.452 e; Centro-Oeste, 6.565.

Tabela 6: Número de Funções Docentes na rede pública e privada de Educação Básica (2010-2013)

\begin{tabular}{|l||c|c|c||c|c|c||c|c|c||c|c|c|}
\hline \multicolumn{1}{|c|}{} & \multicolumn{3}{|c|}{$\mathbf{2 0 1 0}$} & \multicolumn{3}{c|}{$\mathbf{2 0 1 1}$} & \multicolumn{3}{|c||}{$\mathbf{2 0 1 2}$} & \multicolumn{3}{|c|}{$\mathbf{2 0 1 3}$} \\
\cline { 2 - 12 } & Total & $\begin{array}{c}\text { Públi } \\
\text { ca }\end{array}$ & $\begin{array}{c}\text { Priva } \\
\text { da }\end{array}$ & Total & $\begin{array}{c}\text { Públi } \\
\text { ca }\end{array}$ & $\begin{array}{c}\text { Priva } \\
\text { da }\end{array}$ & Total & $\begin{array}{c}\text { Públi } \\
\text { ca }\end{array}$ & $\begin{array}{c}\text { Priva } \\
\text { da }\end{array}$ & Total & $\begin{array}{c}\text { Públi } \\
\text { ca }\end{array}$ & $\begin{array}{c}\text { Priva } \\
\text { da }\end{array}$ \\
\hline Brasil & 2.005 & 1.554 & 450. & 2.045 & 1.571 & 473. & 2.101 & 1.605 & 496. & 2.148 & 1.637 & 510. \\
& .734 & .744 & 990 & .350 & .570 & 780 & .408 & .099 & 309 & .023 & .091 & 932 \\
\hline Norte & 169. & 151. & 18. & 176. & 156. & 19. & 182. & 161. & 21. & 189. & 167. & 22. \\
& 930 & 567 & 363 & 195 & 767 & 428 & 119 & 063 & 056 & 868 & 481 & 387 \\
\hline Norde & 600. & 493. & 107. & 603. & 491. & 111. & 613. & 494. & 119. & 619. & 497. & 121. \\
ste & 796 & 656 & 140 & 359 & 487 & 872 & 367 & 323 & 044 & 358 & 718 & 640 \\
\hline Sudest & 800. & 570. & 229. & 820. & 577. & 242. & 848. & 596. & 251. & 869. & 610. & 258. \\
e & 241 & 752 & 489 & 375 & 505 & 870 & 459 & 532 & 927 & 013 & 092 & 921 \\
\hline Sul & 290. & 227. & 63. & 298. & 233. & 65. & 310. & 240. & 69. & 319. & 246. & 72. \\
& 927 & 135 & 162 & 736 & 203 & 533 & 507 & 753 & 754 & 379 & 951 & 428 \\
\hline Centro & 143. & 110. & 33. & 146. & 112. & 34. & 146. & 112. & 34. & 150. & 114. & 35. \\
-Oeste & 840 & 734 & 106 & 685 & 608 & 077 & 956 & 428 & 528 & 405 & 849 & 556 \\
\hline
\end{tabular}

Fonte: Inep - Sinopse da Educação Básica (anos-base: 2010, 2011, 2012 e 2013).

Quando analisamos as funções docentes tendo em conta as redes pública e privada de Educação Básica (Tabela 6), constatamos que o aumento nas funções docentes diz respeito a 82.347 professores da rede pública e 59.942 professores na rede privada. Relativamente às regiões, na rede pública, houve um aumento de: a) Norte: 15.914 professores; b) Nordeste: 4.062; c) Sudeste: 39.340; d) Sul: 19.816 e; e) Centro-Oeste: 4.115. Na rede privada: a) Norte: 3.751 professores; b) Nordeste: 14.500; c) Sudeste: 29.432; d) Sul: 9.266 e; e) CentroOeste: 2.450 . 


\section{Trabalhonecessário}

Issn: $1808-799 X$

ano 13 , número $21-2015$

Tabela 7 - Formação dos professores da Educação Básica - Brasil e Regiões (2010)

\begin{tabular}{|c|c|c|c|c|c|c|}
\hline \multirow{2}{*}{} & \multirow{2}{*}{ Total } & \multirow{5}{*}{ Professores da Educação Básica (2010) } \\
\cline { 3 - 6 } & & Fundamental & \multicolumn{3}{|c|}{ Escolaridade } \\
\cline { 3 - 6 } & & Médio Total & $\begin{array}{c}\text { Normal/ } \\
\text { Magistério }\end{array}$ & $\begin{array}{c}\text { Ensino } \\
\text { Médio }\end{array}$ & Superior \\
\hline Brasil & 2.005 .734 & 12.565 & 611.260 & 450.707 & 160.553 & 1.381 .909 \\
\hline Norte & 169.930 & 1.792 & 73.029 & 57.007 & 16.022 & 95.109 \\
\hline Nordeste & 600.796 & 6.597 & 288.748 & 220.231 & 68.517 & 305.451 \\
\hline Sudeste & 800.241 & 1.860 & 163.503 & 119.674 & 43.829 & 634.878 \\
\hline Sul & 290.927 & 1.574 & 58.723 & 39.735 & 18.988 & 230.630 \\
\hline $\begin{array}{c}\text { Centro- } \\
\text { Oeste }\end{array}$ & 143.840 & 742 & 27.257 & 14.060 & 13.197 & 115.841 \\
\hline
\end{tabular}

Fonte: Inep - Sinopse da Educação Básica (anos-base: 2010, 2011, 2012 e 2013).

Tabela 8 - Formação dos professores da Educação Básica - Brasil e Regiões (2011)

\begin{tabular}{|l|l|l|l|l|l|l|}
\hline \multirow{2}{*}{} & \multirow{2}{*}{ Total } & \multirow{5}{*}{ Professores da Educação Básica (2011) } \\
\cline { 3 - 7 } & & \multirow{5}{*}{ Fundamental } & \multicolumn{4}{|c|}{ Escolaridade } \\
\cline { 3 - 7 } & & & Médio Total & Normal/Magistério & $\begin{array}{c}\text { Ensino } \\
\text { Médio }\end{array}$ & Superior \\
\hline Brasil & 2.045 .350 & 11.363 & 518.665 & 387.583 & 131.082 & 1.515 .322 \\
\hline Norte & 176.195 & 1.637 & 61.948 & 46.799 & 15.149 & 112.610 \\
\hline Nordeste & 603.359 & 6.049 & 246.650 & 188.251 & 58.399 & 350.660 \\
\hline Sudeste & 820.375 & 1.661 & 141.884 & 108.197 & 33.687 & 676.830 \\
\hline Sul & 298.736 & 1.372 & 45.850 & 32.571 & 13.279 & 251.514 \\
\hline $\begin{array}{l}\text { Centro- } \\
\text { Oeste }\end{array}$ & 146.685 & 644 & 22.333 & 11.765 & 10.568 & 123.708 \\
\hline
\end{tabular}

Fonte: Inep - Sinopse da Educação Básica (anos-base: 2010, 2011, 2012 e 2013). 


\section{Trabalhonecessário}

Issn: $1808-799 X$

ano 13, número $21-2015$

Tabela 9 - Formação dos professores da Educação Básica - Brasil e Regiões (2012)

\begin{tabular}{|l|l|l|l|l|l|l|}
\hline \multirow{2}{*}{} & \multirow{2}{*}{ Total } & \multirow{5}{|c|}{ Professores da Educação Básica (2012) } \\
\cline { 3 - 7 } & & \multirow{5}{*}{ Fundamental } & \multicolumn{4}{|c|}{ Escolaridade } \\
\cline { 3 - 7 } & & Médio Total & Normal/Magistério & $\begin{array}{l}\text { Ensino } \\
\text { Médio }\end{array}$ & Superior \\
\hline Brasil & 2.101 .408 & 8.339 & 450.874 & 335.418 & 115.456 & 1.642 .195 \\
\hline Norte & 182.119 & 1.364 & 50.645 & 35.779 & 14.866 & 130.110 \\
\hline Nordeste & 613.367 & 3.872 & 212.555 & 162.279 & 50.276 & 396.940 \\
\hline Sudeste & 848.459 & 1.354 & 128.252 & 100.048 & 28.204 & 718.853 \\
\hline Sul & 310.507 & 1.176 & 42.597 & 29.272 & 13.325 & 266.734 \\
\hline $\begin{array}{l}\text { Centro- } \\
\text { Oeste }\end{array}$ & 146.956 & 573 & 16.825 & 8.040 & 8.785 & 129.558 \\
\hline
\end{tabular}

Fonte: Inep - Sinopse da Educação Básica (anos-base: 2010, 2011, 2012 e 2013).

Tabela 10 - Formação dos professores da Educação Básica - Brasil e Regiões (2013)

\begin{tabular}{|c|c|c|c|c|c|c|}
\hline & \multicolumn{6}{|c|}{ Professores da Educação Básica (2013) } \\
\hline & \multirow{3}{*}{ Total } & \multicolumn{5}{|c|}{$\begin{array}{l}\text { Escolaridade } \\
\end{array}$} \\
\hline & & \multirow[b]{2}{*}{ Fundamental } & \multicolumn{3}{|c|}{ Ensino Médio } & \multirow[b]{2}{*}{ Superior } \\
\hline & & & Médio Total & Normal/Magistério & $\begin{array}{l}\text { Ensino } \\
\text { Médio }\end{array}$ & \\
\hline Brasil & 2.148 .023 & 6.438 & 534.404 & 297.880 & 236.524 & 1.607.181 \\
\hline Norte & 189.868 & 1.189 & 63.887 & 30.425 & 33.462 & 124.792 \\
\hline Nordeste & 619.358 & 2.618 & 245.478 & 141.922 & 103.556 & 371.262 \\
\hline Sudeste & 869.013 & 1.290 & 149.329 & 93.850 & 55.479 & 718.394 \\
\hline Sul & 319.379 & 990 & 55.994 & 25.364 & 30.630 & 262.395 \\
\hline $\begin{array}{c}\text { Centro- } \\
\text { Oeste }\end{array}$ & 150.405 & 351 & 19.716 & 6.319 & 13.397 & 130.338 \\
\hline
\end{tabular}

Fonte: Inep - Sinopse da Educação Básica (anos-base: 2010, 2011, 2012 e 2013). 


\section{Trabalhonecessário}

Issn: $1808-799 X$

ano 13, número $21-2015$

Tabela 11 - Percentual da formação dos professores da Educação Básica - Brasil e Regiões (2010-2013)

\begin{tabular}{|c|c|c|c|c|c|c|c|c|c|c|c|c|}
\hline & \multicolumn{12}{|c|}{ Escolaridade } \\
\hline & \multirow{2}{*}{\multicolumn{4}{|c|}{ Fundamental }} & \multirow{2}{*}{\multicolumn{4}{|c|}{$\begin{array}{c}\text { Ensino Médio } \\
\text { Médio Total }\end{array}$}} & \multirow{2}{*}{\multicolumn{4}{|c|}{ Superior }} \\
\hline & & & & & & & & & & & & \\
\hline & $\begin{array}{c}201 \\
0\end{array}$ & $\begin{array}{c}201 \\
1\end{array}$ & $\begin{array}{c}201 \\
2\end{array}$ & $\begin{array}{c}201 \\
3\end{array}$ & 2010 & 2011 & 2012 & 2013 & 2010 & 2011 & 2012 & 2013 \\
\hline Brasil & $\begin{array}{l}0,6 \\
\%\end{array}$ & $\begin{array}{l}0,5 \\
\%\end{array}$ & $\begin{array}{l}0,4 \\
\%\end{array}$ & $\begin{array}{l}0,3 \\
\%\end{array}$ & $\begin{array}{c}30,4 \\
\%\end{array}$ & $\begin{array}{c}25,3 \\
\%\end{array}$ & $\begin{array}{c}21,4 \\
\%\end{array}$ & $\begin{array}{c}24,9 \\
\%\end{array}$ & $\begin{array}{c}68,9 \\
\%\end{array}$ & $\begin{array}{c}74,0 \\
\%\end{array}$ & $\begin{array}{c}78,1 \\
\%\end{array}$ & $\begin{array}{c}74,8 \\
\%\end{array}$ \\
\hline Norte & $\begin{array}{l}1,0 \\
\%\end{array}$ & $\begin{array}{l}0,9 \\
\%\end{array}$ & $\begin{array}{l}0,7 \\
\%\end{array}$ & $\begin{array}{l}0,6 \\
\%\end{array}$ & $43 \%$ & $\begin{array}{c}35,1 \\
\%\end{array}$ & $\begin{array}{c}27,8 \\
\%\end{array}$ & $\begin{array}{c}33,6 \\
\%\end{array}$ & $\begin{array}{c}55,9 \\
\%\end{array}$ & $\begin{array}{c}63,9 \\
\%\end{array}$ & $\begin{array}{c}71,4 \\
\%\end{array}$ & $\begin{array}{c}65,7 \\
\%\end{array}$ \\
\hline Nordeste & $\begin{array}{l}1,0 \\
\%\end{array}$ & $1 \%$ & $\begin{array}{l}0,6 \\
\%\end{array}$ & $\begin{array}{c}0,4 \\
\%\end{array}$ & $\begin{array}{c}48,0 \\
\%\end{array}$ & $\begin{array}{c}40,8 \\
\%\end{array}$ & $\begin{array}{c}34,6 \\
\%\end{array}$ & $\begin{array}{c}39,6 \\
\%\end{array}$ & $\begin{array}{c}50,8 \\
\%\end{array}$ & $\begin{array}{c}58,1 \\
\%\end{array}$ & $\begin{array}{c}64,7 \\
\%\end{array}$ & $\begin{array}{c}59,9 \\
\%\end{array}$ \\
\hline Sudeste & $\begin{array}{l}0,2 \\
\%\end{array}$ & $\begin{array}{l}0,2 \\
\%\end{array}$ & $\begin{array}{l}0,1 \\
\%\end{array}$ & $\begin{array}{l}0,1 \\
\%\end{array}$ & $\begin{array}{c}20,4 \\
\%\end{array}$ & $\begin{array}{c}17,3 \\
\%\end{array}$ & $\begin{array}{c}15,1 \\
\%\end{array}$ & $\begin{array}{c}17,1 \\
\%\end{array}$ & $\begin{array}{c}79,3 \\
\%\end{array}$ & $\begin{array}{c}82,5 \\
\%\end{array}$ & $\begin{array}{c}84,7 \\
\%\end{array}$ & $\begin{array}{c}82,7 \\
\%\end{array}$ \\
\hline Sul & $\begin{array}{c}0,5 \\
\%\end{array}$ & $\begin{array}{l}0,4 \\
\%\end{array}$ & $\begin{array}{l}0,3 \\
\%\end{array}$ & $\begin{array}{c}0,3 \\
\%\end{array}$ & $\begin{array}{c}20,1 \\
\%\end{array}$ & $\begin{array}{c}15,3 \\
\%\end{array}$ & $\begin{array}{c}13,7 \\
\%\end{array}$ & $\begin{array}{c}17,5 \\
\%\end{array}$ & $\begin{array}{c}79,2 \\
\%\end{array}$ & $\begin{array}{c}84,1 \\
\%\end{array}$ & $\begin{array}{c}85,9 \\
\%\end{array}$ & $\begin{array}{c}82,2 \\
\%\end{array}$ \\
\hline $\begin{array}{l}\text { Centro- } \\
\text { Oeste }\end{array}$ & $\begin{array}{l}0,5 \\
\%\end{array}$ & $\begin{array}{c}0,4 \\
\%\end{array}$ & $\begin{array}{l}0,3 \\
\%\end{array}$ & $\begin{array}{c}0,2 \\
\%\end{array}$ & $\begin{array}{c}18,9 \\
\%\end{array}$ & $\begin{array}{c}15,2 \\
\%\end{array}$ & $\begin{array}{c}11,4 \\
\%\end{array}$ & $\begin{array}{c}13,1 \\
\%\end{array}$ & $\begin{array}{c}80,5 \\
\%\end{array}$ & $\begin{array}{c}84,3 \\
\%\end{array}$ & $\begin{array}{c}88,1 \\
\%\end{array}$ & $\begin{array}{c}86,7 \\
\%\end{array}$ \\
\hline
\end{tabular}

Fonte: Inep - Sinopse da Educação Básica (anos-base: 2010, 2011, 2012 e 2013).

Quando perguntamos pela formação dos professores que atuavam na Educação Básica entre 2010 e 2013 (Tabelas 7, 8, 9, 10 e 11), constatamos que um número considerável de professores ainda não possui formação em nível superior.

Gráfico 5: Evolução do percentual de professores com formação em nível de Ensino Fundamental - Brasil e Regiões (2010-2013)

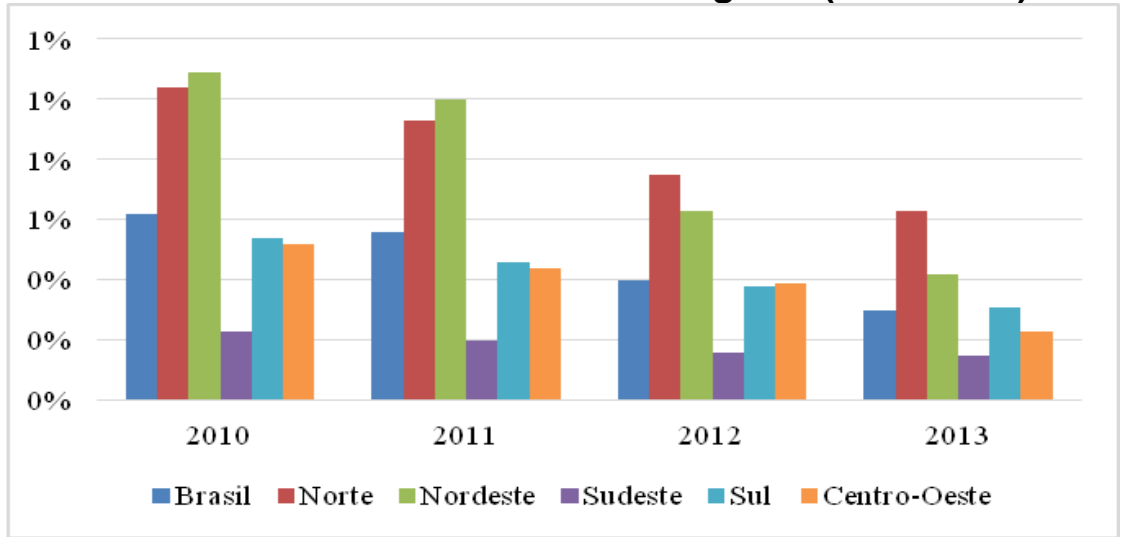

Fonte: Inep - Sinopse da Educação Básica (anos-base: 2010, 2011, 2012 e 2013).

TrabalhoNecessário - www.uff.br/trabalhonecessario; Ano 13, № 21/2015. 


\section{Trabalhonecessário}

Issn: $1808-799 X$

ano 13, número $21-2015$

Gráfico 6: Evolução do percentual de professores com formação em nível de Ensino Médio - Brasil e Regiões (2010-2013)

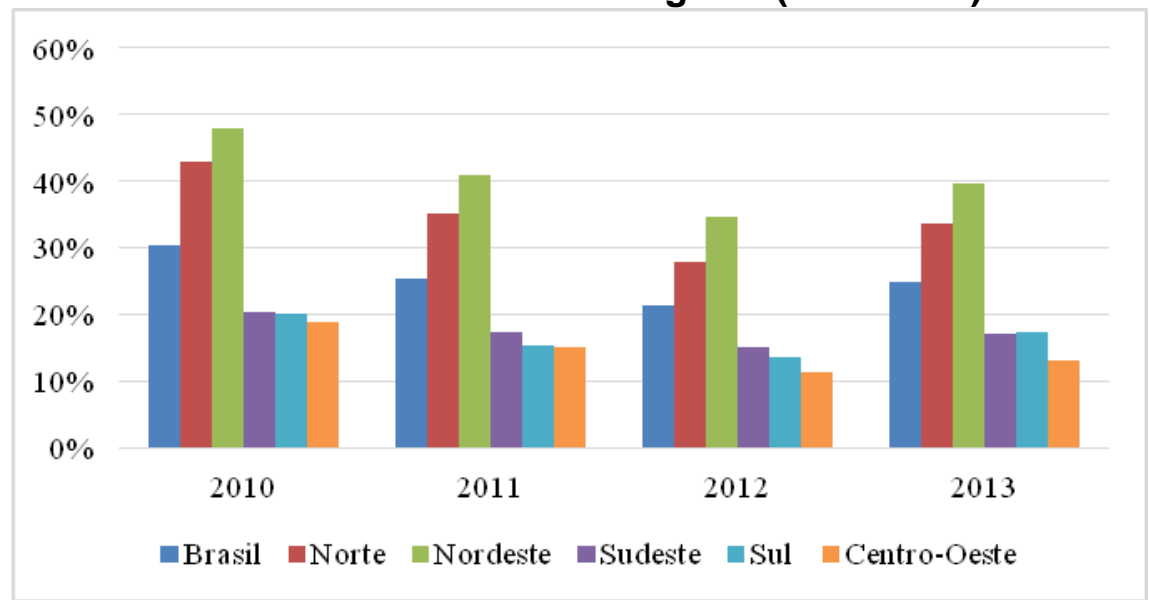

Fonte: Inep - Sinopse da Educação Básica (anos-base: 2010, 2011, 2012 e 2013).

\section{Gráfico 7: Evolução do percentual de professores com formação em nível Superior} - Brasil e Regiões (2010-2013)

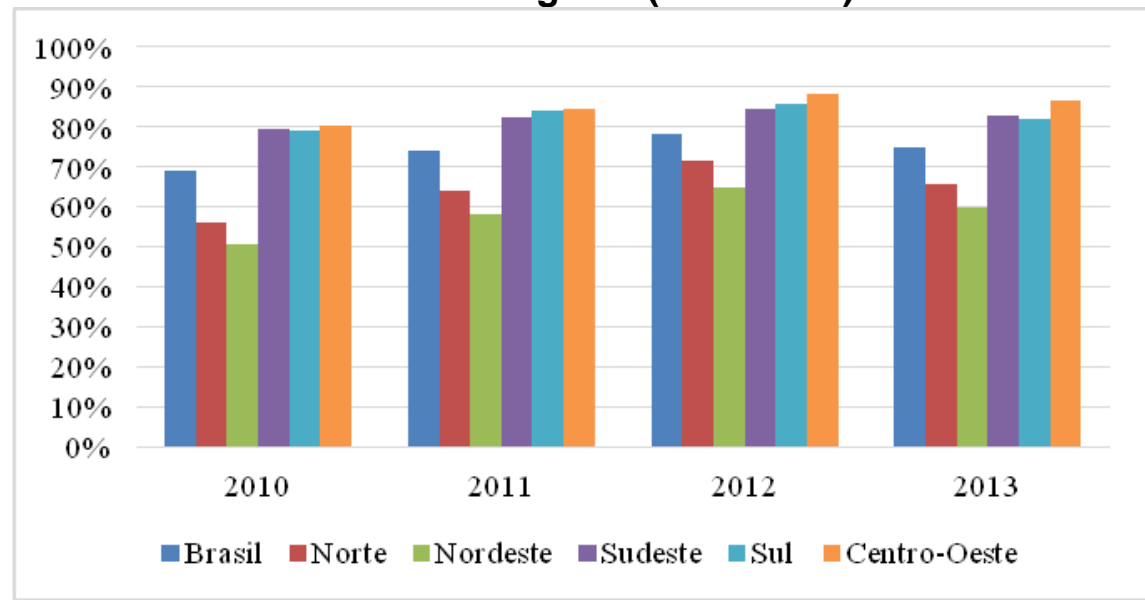

Fonte: Inep - Sinopse da Educação Básica (anos-base: 2010, 2011, 2012 e 2013).

Neste período, houve um aumento do número de professores com formação em nível superior, tanto nacional quanto regionalmente (Gráfico 7). Entretanto, observa-se um decréscimo, absoluto e percentual, nos anos de 2012 e 2013. Este decréscimo contrasta com o aumento, no mesmo período, do 


\section{Trabalhonecessário}

Issn: $1808-799 X$

ano 13, número $21-2015$

número de professores com formação em nível médio (Ensino Médio e/ou Normal/Magistério).

O país ainda possui professores com formação em nível de Ensino Fundamental a trabalhar na Educação Básica, embora este número esteja a diminuir anualmente. As Regiões Norte e Nordeste são as regiões que apresentavam, em 2013, o maior percentual de professores com este nível de formação - 0,63\% (1.189 professores) e 0,42\% (2.618 professores), respectivamente (Gráfico 5).

Há um percentual elevado de professores com formação em nível médio em todas as regiões do país, sendo que, em 2013, as regiões Norte $(33,65 \%)$ e Nordeste $(39,63 \%)$ apresentaram o maior percentual, os quais são superiores à média nacional (24,9\%) (Gráfico 6).

Estes dados evidenciam que cerca de 1/3 destes professores não possuía formação em nível superior entre 2010 e 2013. A qualificação destes professores é ainda uma demanda objetiva a ser atendida pelo governo brasileiro. Taffarel, Rodrigues e Morschbacher (2013) indicam que, em 2013, haviam 28 programas do governo federal, aplicados em caráter emergencial e voltados para a formação dos professores já inseridos na Educação Básica ou em formação. Estes programas abrangem a formação (presencial ou a distância) em nível superior, de aperfeiçoamento ou de pós-graduação e integram a Política Nacional de Formação de Profissionais do Magistério da Educação Básica, que visa a promoção da qualidade da educação básica brasileira. 


\section{Trabalhonecessário}

Issn: $1808-799 X$

ano 13 , número $21-2015$

Tabela 12: Formação em nível Superior dos professores da Educação Básica Brasil e Regiões (2013)

\begin{tabular}{|c|c|c|c|c|}
\hline \multirow{3}{*}{$\begin{array}{c}\text { Unidade } \\
\text { da } \\
\text { Federação }\end{array}$} & \multicolumn{4}{|c|}{ Funções Docentes na Educação Básica (2013) } \\
\hline & \multirow[b]{2}{*}{$\begin{array}{l}\text { Total } \\
\text { Geral }\end{array}$} & \multirow[b]{2}{*}{$\begin{array}{c}\text { Possui Curso } \\
\text { com } \\
\text { Licenciatura }\end{array}$} & \multicolumn{2}{|c|}{ Possui Curso sem Licenciatura } \\
\hline & & & Total & $\begin{array}{c}\text { Com } \\
\text { Complementação } \\
\text { Pedagógica }\end{array}$ \\
\hline Brasil & 1.607 .181 & 1.405 .696 & 201.485 & 97.687 \\
\hline Norte & 124.792 & 113.994 & 10.798 & 5.930 \\
\hline Nordeste & 371.262 & 317.727 & 53.535 & 39.660 \\
\hline Sudeste & 718.394 & 628.030 & 90.364 & 27.134 \\
\hline Sul & 262.395 & 233.912 & 28.483 & 15.785 \\
\hline $\begin{array}{l}\text { Centro- } \\
\text { Oeste }\end{array}$ & 130.338 & 112.033 & 18.305 & 9.178 \\
\hline
\end{tabular}

Fonte: Inep - Sinopse da Educação Básica (anos-base: 2010, 2011, 2012 e 2013).

Tabela 13: Formação em nível Superior dos professores da Educação Básica Brasil e Regiões (2012)

\begin{tabular}{|l|c|c|c|c|}
\hline \multirow{2}{*}{$\begin{array}{c}\text { Unidade } \\
\text { da }\end{array}$} & \multicolumn{4}{|c|}{ Funções Docentes na Educação Básica (2012) } \\
\cline { 2 - 5 } Federação & $\begin{array}{c}\text { Total } \\
\text { Geral }\end{array}$ & $\begin{array}{c}\text { Possui Curso } \\
\text { com } \\
\text { Licenciatura }\end{array}$ & Total & $\begin{array}{c}\text { Possui Curso sem Licenciatura } \\
\text { Complementação } \\
\text { Pedagógica }\end{array}$ \\
\hline Brasil & 1.642 .195 & 1.418 .418 & 223.777 & 112.233 \\
\hline Norte & 130.110 & 118.391 & 11.719 & 7.057 \\
\hline Nordeste & 396.940 & 340.441 & 56.499 & 40.419 \\
\hline Sudeste & 718.853 & 612.206 & 106.647 & 37.442 \\
\hline Sul & 266.734 & 236.392 & 30.342 & 17.381 \\
\hline $\begin{array}{l}\text { Centro- } \\
\text { Oeste }\end{array}$ & 129.558 & 110.988 & 18.570 & 9.934 \\
\hline
\end{tabular}

Fonte: Inep - Sinopse da Educação Básica (anos-base: 2010, 2011, 2012 e 2013). 


\section{Trabalhonecessário}

Issn: $1808-799 X$

ano 13 , número $21-2015$

Tabela 14: Formação em nível Superior dos professores da Educação Básica Brasil e Regiões (2011)

\begin{tabular}{|c|c|c|c|c|}
\hline \multirow{3}{*}{$\begin{array}{c}\text { Unidade } \\
\text { da } \\
\text { Federação }\end{array}$} & \multicolumn{4}{|c|}{ Funções Docentes na Educação Básica (2011) } \\
\hline & \multirow[b]{2}{*}{$\begin{array}{l}\text { Total } \\
\text { Geral }\end{array}$} & \multirow[b]{2}{*}{$\begin{array}{c}\text { Possui Curso } \\
\text { com } \\
\text { Licenciatura }\end{array}$} & \multicolumn{2}{|c|}{ Possui Curso sem Licenciatura } \\
\hline & & & Total & $\begin{array}{c}\text { Com } \\
\text { Complementação } \\
\text { Pedaqóqica }\end{array}$ \\
\hline Brasil & 1.515 .322 & 1.249 .509 & 265.813 & 194.629 \\
\hline Norte & 112.610 & 100.671 & 11.939 & 7.485 \\
\hline Nordeste & 350.660 & 288.253 & 62.407 & 44.238 \\
\hline Sudeste & 676.830 & 535.804 & 141.026 & 108.831 \\
\hline Sul & 251.514 & 218.846 & 32.668 & 20.614 \\
\hline $\begin{array}{l}\text { Centro- } \\
\text { Oeste }\end{array}$ & 123.708 & 105.935 & 17.773 & 13.461 \\
\hline
\end{tabular}

Fonte: Inep - Sinopse da Educação Básica (anos-base: 2010, 2011, 2012 e 2013).

Tabela 15: Formação em nível Superior dos professores da Educação Básica Brasil e Regiões (2010)

\begin{tabular}{|l|c|c|c|c|}
\hline \multirow{2}{*}{$\begin{array}{c}\text { Unidade } \\
\text { da } \\
\begin{array}{c}\text { Federaçã } \\
\text { o }\end{array}\end{array}$} & \multirow{4}{|c|}{ Total } & \begin{tabular}{c} 
Possui curso \\
com \\
\cline { 3 - 5 }
\end{tabular} & $\begin{array}{c}\text { Possui curso } \\
\text { Licenciatura }\end{array}$ & $\begin{array}{c}\text { Possui cursos } \\
\text { Licenciatura } \\
\text { com e sem } \\
\text { licenciatura }\end{array}$ \\
\hline Brasil & 1.381 .909 & 1.297 .940 & 63.726 & 20.243 \\
\hline Norte & 95.109 & 82.831 & 11.619 & 659 \\
\hline Nordeste & 305.451 & 287.992 & 16.560 & 899 \\
\hline Sudeste & 634.878 & 608.162 & 16.365 & 10.351 \\
\hline Sul & 230.630 & 214.566 & 14.514 & 1.550 \\
\hline $\begin{array}{l}\text { Centro- } \\
\text { Oeste }\end{array}$ & 115.841 & 104.389 & 4.668 & 6.784 \\
\hline
\end{tabular}

Fonte: Inep - Sinopse da Educação Básica (anos-base: 2010, 2011, 2012 e 2013). 


\section{Trabalhonecessário}

Issn: $1808-799 X$

ano 13, número $21-2015$

Tabela 16: Percentual do número de professores da Educação Básica com Formação em nível Superior - Brasil e Regiões (2011-2013) ${ }^{3}$

\begin{tabular}{|l|c|c|c||c|c|c|}
\hline \multirow{2}{*}{$\begin{array}{c}\text { Unidade } \begin{array}{c}\text { Und } \\
\text { da }\end{array} \\
\begin{array}{l}\text { Federaçã } \\
\mathbf{0}\end{array}\end{array}$} & \multicolumn{3}{|c|}{$\begin{array}{c}\text { Possui curso com } \\
\text { Licenciatura }\end{array}$} & \multicolumn{3}{c|}{$\begin{array}{c}\text { Possui curso sem } \\
\text { Licenciatura }\end{array}$} \\
\cline { 2 - 7 } & $\mathbf{2 0 1 1}$ & $\mathbf{2 0 1 2}$ & $\mathbf{2 0 1 3}$ & $\mathbf{2 0 1 1}$ & $\mathbf{2 0 1 2}$ & $\mathbf{2 0 1 3}$ \\
\hline Brasil & $82,46 \%$ & $86,37 \%$ & $87,46 \%$ & $17,54 \%$ & $13,63 \%$ & $12,54 \%$ \\
\hline Norte & $89,37 \%$ & $90,99 \%$ & $91,35 \%$ & $10,63 \%$ & $9,01 \%$ & $8,65 \%$ \\
\hline Nordeste & $82,20 \%$ & $85,77 \%$ & $85,58 \%$ & $17,79 \%$ & $14,23 \%$ & $14,42 \%$ \\
\hline Sudeste & $79,16 \%$ & $85,16 \%$ & $87,42 \%$ & $20,84 \%$ & $14,84 \%$ & $12,58 \%$ \\
\hline Sul & $87,01 \%$ & $88,62 \%$ & $89,14 \%$ & $12,99 \%$ & $11,38 \%$ & $10,86 \%$ \\
\hline $\begin{array}{l}\text { Centro- } \\
\text { Oeste }\end{array}$ & $85,63 \%$ & $85,67 \%$ & $85,96 \%$ & $14,37 \%$ & $14,33 \%$ & $14,04 \%$ \\
\hline
\end{tabular}

Fonte: Adaptado de Inep - Sinopse da Educação Básica

(anos-base: 2010, 2011, 2012 e 2013).

Dos professores que atuavam na Educação Básica no período de 2011 a 2013 e que possuíam formação em nível superior, prepondera a formação em cursos de Licenciatura. De acordo com as Tabelas 12, 13, 14, 15 e 16, o número de professores com formação em curso de Licenciatura, em nível nacional, aumentou entre os anos de 2011 e 2012. Dos professores com formação em nível superior sem curso de Licenciatura, há um aumento anual do número de professores com complementação pedagógica e uma diminuição anual do número de professores sem curso de Licenciatura. Em 2011, de acordo com os dados nacionais, $82,46 \%$ dos professores com formação superior possuíam curso de Licenciatura e, em 2013, este percentual se elevou para $87,46 \%$. O percentual de professores com formação superior, mas sem curso de Licenciatura, diminuiu de $17,54 \%$ em 2011 para 12,54\% em 2013.

\footnotetext{
${ }^{3}$ A Sinopse da Educação Básica do ano de 2010 não especifica o número de professores que possui complementação pedagógica. Por esta razão, não incluímos os dados deste ano.
}

TrabalhoNecessário - www.uff.br/trabalhonecessario; Ano 13, № 21/2015. 


\section{Trabalhonecessário}

Issn: $1808-799 X$

ano 13, número $21-2015$

Tabela 17: Número de Cursos de Licenciatura Presenciais e a Distância- 2010-2013

\begin{tabular}{|c|c|c|c||c|c|c|}
\hline \multirow{2}{*}{ Ano } & \multicolumn{3}{|c||}{ Presencial } & \multicolumn{3}{c|}{ A Distância } \\
\cline { 2 - 7 } & Total & Público & Privado & Total & Público & Privado \\
\hline 2010 & 7.370 & 3.504 & 3.826 & 518 & 328 & 190 \\
\hline 2011 & 7.344 & 3.678 & 3.666 & 554 & 361 & 193 \\
\hline $2012^{4}$ & N.d. & N. d. & N. d. & N. d. & N. d. & N. d. \\
\hline 2013 & 7.311 & 3.972 & 3.339 & 589 & 364 & 225 \\
\hline
\end{tabular}

Fonte: Inep - Sinopse da Educação Superior (anos-base: 2010, 2011 e 2013).

Acerca dos cursos de Licenciatura ofertados por IES públicas e privadas, constata-se que o país apresentou, no período de 2010 a 2013, uma média de 7.300 cursos presenciais e de 550 cursos a distância (Tabela 17).

Quanto aos cursos de licenciatura presenciais, observamos um relativo "equilíbrio" entre as IES públicas e as IES privadas. A partir do ano de 2013, temse um maior número de cursos de licenciatura provenientes das IES públicas. Cabe destacar, ainda, que o Brasil é um país em que o número de IES privadas é muito superior ao número de IES públicas. De acordo com os dados da Sinopse da Educação Superior do Inep, no ano de 2013, de um total de 2.391 IES, 301 eram públicas e 2.090, privadas.

A política de expansão do Ensino Superior desenvolvida pelo governo federal na última década abrange, por um lado, a expansão do ensino superior público com a criação de novas universidades e de novos cursos, a ampliação de vagas nas universidades públicas já existentes e o ingresso pelo sistema de cotas e; por outro, abrange o incentivo ao ingresso no ensino superior privado mediante programas de financiamento (como o Fies - Programa de Financiamento do Ensino Superior) e de bolsas de gratuidade das taxas mensais (como o Prouni Programa Universidade para Todos).

No caso do ensino superior público, os recursos destinados não são compatíveis com as necessidades desencadeadas pela expansão e se tem um

\footnotetext{
${ }^{4}$ A Sinopse da Educação Superior referente ao ano de 2012 não foi disponibilizada pelo Inep.
} 


\section{Trabalhonecessário}

Issn: $1808-799 X$

ano 13, número $21-2015$

processo de expansão sem qualidade (insuficiente assistência estudantil, infraestrutura deficitária, contratação insuficiente de docentes e servidores técnico-administrativos, intensificação do trabalho dos docentes e dos servidores técnico-administrativos, etc.). No âmbito do ensino superior privado, tem-se a destinação de recursos públicos no setor privado em detrimento de uma política consistente de expansão do ensino superior público.

Tabela 18: Número de Matrículas em Cursos de Licenciatura Presenciais e a Distância- Brasil (2010-2013)

\begin{tabular}{|c|c|c|c||c|c|c|}
\hline \multirow{2}{*}{ Ano } & \multicolumn{3}{|c|}{ Presencial } & \multicolumn{3}{c|}{ A Distância } \\
\cline { 2 - 7 } & Total & Público & Privado & Total & Público & Privado \\
\hline 2010 & 923.510 & 454.041 & 469.469 & 425.355 & 102.098 & 323.257 \\
\hline 2011 & 926.641 & 480.448 & 446.193 & 428.277 & 103.853 & 324.424 \\
\hline 2012 & N. d. & N. d. & N. d. & N. d. & N. d. & N. d. \\
\hline 2013 & 922.185 & 500.057 & 422.128 & 449.582 & 96.662 & 352.920 \\
\hline
\end{tabular}

Fonte: Inep - Sinopse da Educação Superior (anos-base: 2010, 2011 e 2013).

O "equilíbrio" em termos de número de cursos de licenciatura na modalidade presencial é também observado nas matrículas nestes cursos (Tabela 18). Em 2010, o número de matrículas nos cursos de licenciatura presenciais nas IES públicas era inferior às matrículas dos cursos de licenciatura presenciais nas IES privadas (uma diferença de 15.428 matrículas). Entretanto, a partir de 2011, as matrículas nos cursos de licenciatura em IES públicas ultrapassaram o número de matrículas nos cursos de licenciatura em IES privadas. Em 2013, esta diferença é de 77.929 matrículas.

Os cursos de licenciatura a distância encontram-se em expansão no país. Entre os anos de 2010 e 2013, o país teve um aumento de 71 cursos, sendo 36 cursos em IES públicas e 35 em IES privadas (Tabela 17). Embora as IES públicas possuíssem, entre 2010 e 2013, cursos de licenciatura a distância em número superior às IES privadas (2010, 138 cursos a mais; 2011, 168 e; 2013, 139), a quantidade de matrículas nos cursos de licenciatura nesta modalidade nas IES privadas é muito superior ao número de matrículas nas IES públicas. 


\section{Trabalhonecessário}

Issn: $1808-799 X$

ano 13, número $21-2015$

Conforme os dados da Tabela 18, as matrículas nas IES privadas correspondem, em 2013, a 78,5\% matrículas nos cursos de licenciatura a distância.

Esta breve caracterização da situação da Educação Básica brasileira (em termos de número de matrículas, de escolas e de professores, bem como da situação da formação destes professores, número de cursos de licenciatura e de matrículas) nos permite sistematizar alguns apontamentos:

a) A população brasileira é atendida, ao nível da Educação Básica, predominantemente pela rede pública;

b) A rede privada se encontra em expansão na Educação Básica, o que pode ser identificado pelo aumento do número de escolas e de matrículas entre 2010 e 2013;

c) A diminuição no número de matrículas e de escolas na Educação Básica neste período ocorreu exclusivamente na rede pública;

d) $O$ aumento anual do número de professores que atuavam na Educação Básica entre 2010 e 2013 deu-se tanto na rede pública quanto na rede privada;

e) $1 / 3$ dos professores que trabalhavam na Educação Básica não tinham formação em nível superior;

f) A formação em nível superior, em cursos de licenciatura presenciais ou a distância, é atendida tanto por IES públicas quanto privadas. No âmbito das matrículas em cursos de licenciatura, as IES públicas e privadas apresentam certo equilíbrio na modalidade presencial. Entretanto, quanto às matrículas nos cursos de licenciatura ofertados a distância, há a predominância das IES privadas;

g) O problema da formação dos professores da Educação Básica, em termos quantitativos e qualitativos tem sido enfrentado tanto por programas emergenciais quanto pela expansão do acesso ao Ensino Superior. Carece-se de estudos que avaliem estes programas do ponto de vista do seu alcance, dos 


\section{Trabalhonecessário}

Issn: $1808-799 X$

ano 13, número $21-2015$

objetivos propostos e da base teórica privilegiada para o seu desenvolvimento nas diversas regiões do país. Apontamentos preliminares, como os de Rodrigues e Morschbacher (2013), colocam em questão o fato destes programas serem políticas de governo (não de Estado), vincularem-se a editais e possibilitarem o repasse de recursos públicos para a iniciativa privada. No tocante à expansão do acesso ao ensino superior, o repasse de recursos à iniciativa privada e a expansão do Ensino Superior público com insuficiente contrapartida orçamentária revelam a opção do governo brasileiro pela implementação de políticas que procuram conciliar o público com o privado, com privilégios ao segundo.

Frigotto (2011), ao realizar um balanço da educação brasileira na primeira década do século XXI, indicando que o governo brasileiro, (a) por um lado, optou por uma política conciliatória de "uma minoria prepotente a uma maioria desvalida" (p.239), em que se tem tanto a continuidade da "política macroeconômica, fiel aos interesses da classe detentora do capital" quanto o investimento na melhoria de vida de uma fração da classe trabalhadora; e (b) por outro, "não disputou um projeto educacional antagônico, no conteúdo, no método e na forma" (p.241); avalia a lógica das políticas destinadas à formação dos professores da Educação Básica ao afirmar que: "[...] o Estado, em vez de alargar o fundo público na perspectiva do atendimento a políticas públicas de caráter universal, fragmenta as ações em políticas focais que amenizam os efeitos, sem alterar substancialmente as suas determinações." (p.245).

\section{Acerca dos projetos que disputam a direção da formação de professores}

Se a questão da garantia da formação em nível superior de $1 / 3$ dos professores que atuam na Educação Básica, a do acesso e permanência no Ensino Superior, a da expansão, com qualidade, do Ensino Superior público e 


\section{Trabalhonecessário}

Issn: $1808-799 X$

ano 13, número $21-2015$

presencial, a garantia de formação continuada aos professores, etc. são aspectos fundamentais em termos de política pública para a formação dos professores da Educação Básica, a questão da base teórica que orienta e/ou deve orientar a formação destes professores não é uma questão despicienda. É esta base teórica que informa a direção da formação dos professores em termos epistemológicos, científicos, pedagógicos e políticos. Isto, indubitavelmente, tem rebatimentos na formação das crianças, jovens e adultos ao nível da Educação Básica.

A formação dos indivíduos pelas primeiras etapas da formação da classe trabalhadora no contexto formal da escolarização (a Educação Básica) não se dá desconectada da situação de crise do capital. Nesta situação de crise, em que é cada vez mais notória que a tendência ao decréscimo da taxa de lucros está a operar, uma das "alternativas" levadas a cabo pelo grande capital é a diminuição dos "custos" com o trabalho. Neste sentido é que a flexibilização da legislação trabalhista, o corte de direitos sociais são utilizados como meios.

Articulada a esta estratégia está o rebaixamento do valor da força de trabalho, o qual é determinado pelo valor dos meios necessários à subsistência dos trabalhadores. Dentre estes meios de subsistência está a formação dos trabalhadores. O seu rebaixamento compõe uma das estratégias do grande capital para enfrentar a tendência ao decréscimo da taxa de lucro.

O conjunto das reformas educacionais que foram realizadas a partir de meados da década de 1990 no Brasil, em um claro processo de alinhamento às "recomendações" dos organismos financeiros internacionais para a educação (TAFFAREL, 1998; MELO, 2004), representa uma das principais mediações a partir do qual o projeto de rebaixamento da formação da classe trabalhadora é colocado em ação. Este rebaixamento consiste no projeto hegemônico de formação que é veiculado e desenvolvido como idôneo e necessário na atual conjuntura - é o projeto necessário em tempos de fluidez, de rápidas mudanças e das "formas contemporâneas de conviver e de ser" (BRASIL, 2001, p.7). 


\section{Trabalhonecessário}

Issn: $1808-799 X$

ano 13, número $21-2015$

Autores como Santos Jr. et. al (2009), Martins (2010), Santos (2013) e Gama e Santos Jr. (2014) têm demonstrado a tese do rebaixamento da formação da classe trabalhadora em seus estudos. Este rebaixamento se desenvolve de diferentes formas e tanto contribui para a diminuição do valor da força de trabalho quanto limita a capacidade de apreensão, explicação e intervenção na realidade. Esta é uma questão chave em tempos de acirramento da luta de classes, de intensificação da concentração da riqueza e da ofensiva imperialista sobre os países e os trabalhadores, em que a classe trabalhadora é, pelas condições objetivas, chamada à ação organizada e radical no real.

A adoção e implantação do projeto hegemônico de formação pelo Estado brasileiro busca responder às pressões dos trabalhadores pela elevação do seu padrão cultural. De acordo com Albuquerque (2014), este projeto de formação, entretanto, não é capaz de responder a esta aspiração da classe. A luta dos trabalhadores, no plano educacional, portanto, não é somente a do acesso à escolarização em todos os seus níveis, mas também a da base teórica que sustenta e/ou deve sustentar a sua formação.

O rebaixamento da formação da classe trabalhadora expressa-se em diversas frentes, que vão da formação ao nível da escolarização básica à formação dos professores. Não é fortuita a menção das Diretrizes Curriculares Nacionais (DCN) para os cursos de licenciatura (Parecer CNE/CP 09/2001 e Resolução CNE/CP 01/2002) de que uma das suas finalidades é o alinhamento da formação de professores com a reforma operada na Educação Básica.

A reforma da Educação Básica, que se inicia com a Lei de Diretrizes e Bases da Educação Nacional (Lei n. 9.394/1996) e tem continuidade com as DCN da Educação Básica, introduz o desenvolvimento de habilidades e competências e a aprendizagem ao longo da vida como referências para a formação. A adoção destas referências é justificada pelo argumento da necessidade de adequação da formação das crianças, jovens e adultos com a realidade em constante 


\section{Trabalhonecessário}

Issn: $1808-799 X$

ano 13, número $21-2015$

transformação. O processo de escolarização é deslocado da incumbência do domínio do conhecimento para o desenvolvimento da constante prontidão para aprender.

A formação dos professores para a Educação Básica não fica incólume ao projeto hegemônico da formação da classe trabalhadora. Tal como menciona o documento das DCN, a formação de professores é concebida como um dos instrumentos a partir dos quais o "êxito" da reforma da Educação Básica pode ser garantido. Tem-se um alinhamento da base teórica (epistemológica, pedagógica e política) que sustenta o projeto hegemônico de formação da classe trabalhadora para a formação dos professores.

O ideário do desenvolvimento de competências e de habilidades se articula à concepção do "professor reflexivo", do "saber fazer" do professor e da construção da "identidade pessoal-profissional", que se sobrepõe a qualquer outra forma de conhecimento. Há um sistemático "descarte da teoria, da objetividade e da racionalidade expresso na desqualificação dos conhecimentos clássicos, universais" (MARTINS, 2010, p.20) como base da formação dos professores.

A possibilidade de conhecer a realidade e de elaboração do conhecimento e da verdade objetivos são negadas em favor do irracionalismo e/ou do subjetivismo. Deste modo, as metanarrativas são substituídas pelas "descrições fenomênicas e pelas interpretações consensuais presentes em interpretações primárias (locais, imediatas e fortuitas) com as quais a realidade possa ser identificada" (MARTINS, 2010, p.21).

O "ato de ensinar" é concebido de forma negativa e o "ato de aprendizagem" adquire centralidade. Importa mais a prontidão para a aprendizagem (a atitude de aprender a aprender), a reflexão sobre a própria prática (sobre o cotidiano, sobre o "fazer") e menos o domínio do conhecimento clássico necessário para o desenvolvimento do trabalho educativo. A negação ao 


\section{Trabalhonecessário}

Issn: $1808-799 X$

ano 13, número $21-2015$

acesso ao conhecimento consiste em um dos instrumentos mediante o qual se dá o rebaixamento na formação dos professores e na formação dos trabalhadores.

Há uma diluição cada vez mais rápida, na formação inicial do professor, da linha distintiva da escola como lócus do exercício profissional e a escola como lócus que deve garantir a sua preparação filosófica, teórica e metodológica (MARTINS, 2010). As dimensões técnicas da prática "passam a ocupar um lugar central, em detrimento de seus fundamentos. Privilegia-se a forma mutilada de conteúdo!" (MARTINS, 2010, p.22). Sob o argumento da articulação entre teoria e prática, a reflexão sobre a própria prática e a aprendizagem por resolução de problemas são estratégias privilegiadas para esta articulação. Subjaz à crítica da cisão entre teoria e prática uma compreensão não-dialética e idealista dos fundamentos ontológicos da teoria e da prática.

Como resultado das elaborações científicas contra hegemônicas, materialistas e dialéticas, resultantes da resistência, da organização e da luta dos trabalhadores no âmbito das reivindicações transitórias e históricas, tem-se um projeto de educação (e de formação de professores) não propriamente alternativo, mas, necessariamente antagônico e radical. Este projeto encontra-se em franca disputa com o projeto hegemônico no interior das universidades brasileiras.

Trata-se de um projeto de formação no interior do qual se tem uma posição de classe clara, intrinsecamente articulado com o horizonte histórico de superação da sociedade de classes, com a construção do socialismo como transição ao comunismo.

A sua base teórica é a concepção materialista e dialética da história, a qual funda as posições mais avançadas do ponto de vista científico no âmbito da teoria do conhecimento, da teoria da aprendizagem (psicologia histórico-cultural), da teoria pedagógica (pedagogia histórico-crítica), da metodologia de ensino e do conhecimento específico de cada área de conhecimento. 


\section{Trabalhonecessário}

Issn: $1808-799 X$

ano 13, número $21-2015$

Concebe o ser humano como um ser que produz a sua existência e que se produz enquanto humano mediante a atividade prática de transformação material do real (que é atividade vital - o trabalho). Esta atividade prática é a base de todo o viver, ou seja, a base a partir da qual se desenvolvem todas as relações que sustentam e são sustentadas por este viver.

Em um determinado grau de complexificação do patrimônio acumulado pela humanidade (em que este é, simultaneamente, consequência do processo de produção do viver e base deste mesmo processo), a transmissão deste patrimônio (condição para a humanização) passa a se dar mediante processos sistemáticos - a saber, na e pela educação escolar. A humanização dos seres humanos dá-se pela apropriação deste patrimônio e é função da escola garantir esta apropriação de formação sistemática (SAVIANI, 2012). Neste sentido é que o projeto de formação em exposição defende como base fundamental da formação humana o acesso ao conhecimento historicamente produzido e acumulado nas suas formas mais elaboradas no plano da ciência, da filosofia e da arte.

A base teórica materialista e dialética fornece os instrumentos de método, conceituais e políticos aos professores para a penetração radical no real (afirmando a necessidade objetiva de conhecer a realidade), para a apropriação do conhecimento clássico (base para a humanização), para o desenvolvimento do trabalho educativo em consonância com a tarefa da educação de formação da humanidade em cada indivíduo singular, de formação com consistente base teórica, consciência de classe e formação política.

A formação de professores, com consistente base teórica, que dominam os fundamentos da educação, da aprendizagem e de sua área específica, os métodos e técnicas para a produção do conhecimento científico, as teorias pedagógicas, o conhecimento específico da sua área (dos quais emanam os conteúdos de ensino), os determinantes econômicos, históricos e políticos da educação brasileira e com formação política alinhada com os interesses da classe 


\section{Trabalhonecessário}

Issn: $1808-799 X$

ano 13, número $21-2015$

trabalhadora, é uma das condições para a alteração da organização do trabalho pedagógico na Educação Básica, em resistência e em superação à tendência do rebaixamento da formação dos trabalhadores.

\section{Conclusões}

A educação brasileira padece de problemas que são muito anteriores à intensificação das políticas (neo)liberais da década de 1990. A universalização da Educação Básica, a erradicação do analfabetismo, a universalização da formação em nível superior para os professores da Educação Básica, os planos de carreira e de salários adequados para os profissionais de Educação, etc. são alguns dos problemas que têm sido enfrentados de modo parcial, focalizado, a partir de programas pelo Estado brasileiro.

Se as pressões da classe trabalhadora pelo acesso à Educação Básica e ao Ensino Superior têm se intensificado, ao mesmo tempo, a intensificação da ofensiva do grande capital em crise (que necessita rebaixar o valor da força de trabalho e reduzir a esfera estatal, pública) e a elevação, pelos organismos financeiros, da educação como fator de diminuição da pobreza são fatores a se ter em conta quando da análise das políticas educacionais brasileiras.

Entendemos, portanto, que a forma que as políticas para a formação de professores da Educação Básica tomam - os programas que visam qualificar a formação docente, a expansão deficitária do Ensino Superior público, a expansão do Ensino Superior privado e da educação a distância - expressam, simultaneamente, os rumos da política estatal brasileira, tal como exposto por Frigotto (2010), e a pressão exercida a nível internacional pelo grande capital em crise. O rebaixamento da formação como projeto para a classe trabalhadora e a conversão da educação em mercadoria rentável (ao nível da Educação Básica e, 


\section{Trabalhonecessário}

Issn: $1808-799 X$

ano 13, número $21-2015$

principalmente, do Ensino Superior) são faces de uma mesma moeda que necessitam ser enfrentados a partir de diversas frentes e em ligação com a conjuntura mais geral e com as organizações de trabalhadores que realizam este enfrentamento neste plano mais geral.

No âmbito da formação de professores para a Educação Básica brasileira, destacamos um duplo movimento a ser tido em conta no debate deste tema, na proposição de políticas e na intervenção do rumo destas:

a) Por um lado, a garantia do acesso e da permanência dos professores e futuros professores nos cursos de formação inicial e continuada públicos, de qualidade e presenciais. Não é aspecto secundário que $1 / 3$ dos professores que atuam na Educação Básica em nosso país não possuam formação em nível superior, nomeadamente, em cursos de licenciatura. Também não é secundário que cerca de metade das matrículas em cursos de licenciaturas presenciais se deem em IES privadas e que a formação de professores em nível superior na modalidade a distância esteja em expansão, sobretudo no Ensino Superior privado;

b) Por outro, a necessária disputa, nas IES, escolas de Educação Básica, organizações dos trabalhadores, movimentos sociais e na sociedade em geral, pela direção da formação em geral e dos professores, enfrentando de modo radical e superador o projeto assentado no rebaixamento da formação. A disputa pela direção da formação e os esforços pela implementação do projeto antagônico ao projeto do capital não se faz dissociado da luta concreta da classe trabalhadora, em unidades nas e com as suas organizações, pelas reivindicações transitórias e históricas da classe. 


\section{Trabalhonecessário}

Issn: $1808-799 X$

ano 13, número $21-2015$

\section{Referências}

ALBUQUERQUE, J. Produção do conhecimento sobre a formação dos professores do campo no Brasil: teses e antíteses. Revista HISTEDBR On-line, Campinas, n. 59, p.218-227, 2014.

FRIGOTTO, G. Os circuitos da história e o balanço da educação no Brasil na primeira década do século XXI. Revista Brasileira de Educação, Rio de Janeiro, v. 16, n. 46 p.235-254, 2011.

GAMA, C. N.; SANTOS JR., C. de L. A concepção de formação de professores presente nas teses sobre o currículo de Pedagogia no Brasil: uma análise crítica. Revista HISTEDBR On-line, Campinas, n. 59, p.166-175, 2014.

INEP. Censo da Educação Superior 2012: resumo técnico. Brasília: Inep, 2014.

INEP. Sinopse da Educação Básica 2013. Brasília, 2014. Disponível em: $<$ http://portal.inep.gov.br/basica-censo-escolar-sinopse-sinopse $>$. Acesso em: 30 jan. 2015.

INEP. Sinopse da Educação Básica 2012. Brasília, 2013. Disponível em: $<$ http://portal.inep.gov.br/basica-censo-escolar-sinopse-sinopse $>$. Acesso em: 30 jan. 2015.

INEP. Sinopse da Educação Básica 2011. Brasília, 2012. Disponível em: $<$ http://portal.inep.gov.br/basica-censo-escolar-sinopse-sinopse>. Acesso em: 30 jan. 2015.

INEP. Sinopse da Educação Básica 2010. Brasília, 2011. Disponível em: $<$ http://portal.inep.gov.br/basica-censo-escolar-sinopse-sinopse $>$. Acesso em: 30 jan. 2015.

INEP. Sinopse da Educação Superior 2013. Brasília, 2014. Disponível em: $<$ http://portal.inep.gov.br/superior-censosuperior-sinopse>. Acesso em: 30 jan. 2015.

INEP. Sinopse da Educação Superior 2011. Brasília, 2012. Disponível em: $<$ http://portal.inep.gov.br/superior-censosuperior-sinopse $>$. Acesso em: 30 jan. 2015.

INEP. Sinopse da Educação Superior 2010. Brasília, 2011. Disponível em: $<$ http://portal.inep.gov.br/superior-censosuperior-sinopse>. Acesso em: 30 jan. 2015.

MARTINS, L. M. O legado do século XX para a formação de professores. In: MARTINS, L. M.; DUARTE, N. (Orgs.). Formação de professores: limites contemporâneos e alternativas necessárias. São Paulo: Cultura Acadêmica, 2010. p.13-32.

MELO, A. A. S. de. A mundialização da educação: consolidação do projeto neoliberal na América Latina - Brasil e Venezuela. Maceió: EDUFAL, 2004. 


\section{Trabalhonecessário}

Issn: $1808-799 X$

ano 13, número $21-2015$

RODRIGUES, R. F. C.; MORSCHBACHER, M. Crítica à lógica dos programas para formação de professores: uma análise da Política Nacional de Formação de Profissionais do Magistério da Educação Básica. Salvador, 2013. mimeo.

SANTOS, C. F. dos. Descendo dos ombros dos gigantes: sobre o esvaziamento teórico da formação de professores no Brasil. In: SANTOS, C. F. dos (Org.). Crítica ao esvaziamento da educação escolar. Salvador: EDUNEB, 2013. p.133157.

SANTOS Jr., C. de L. et. al. A base conceitual sobre formação de professores e militantes culturais. In: COLAVOLPE, C. R.; TAFFAREL, C. N. Z.; SANTOS Jr., C. de L. (Orgs.). Trabalho pedagógico e formação de professores/militantes culturais: construindo políticas públicas para a Educação Física, esporte e lazer. Salvador: EDUFBA, 2009. p.33-46.

SAVIANI, D. Pedagogia histórico-crítica: primeiras aproximações. 11.ed. Campinas: Autores Associados, 2012.

SAVIANI, D.; DUARTE, N. (Orgs.). Pedagogia histórico-crítica e luta de classes na educação escolar. Campinas: Autores Associados, 2012.

TAFFAREL, C. Z. A formação profissional e as diretrizes curriculares do programa nacional de graduação: 0 assalto às consciências e o amoldamento subjetivo. Revista da Educação Física, Maringá, v. 9, n. 1, p.13-23, 1998.

TAFFAREL, C. Z.; RODRIGUES, R. F.; MORSCHBACHER, M. A perspectiva da formação docente: analisando reivindicações históricas. Universidade $e$ Sociedade, Brasília, n. 51, p.60-73, 2013.

Recebido em 25 de julho de 2015. Aprovado em 11 de agosto de 2015. 